\title{
THE MODEL OF STUDENTS ENGLISH CLUB CONTRIBUTION TO WRITING MOTIVATION AND PUNCTUATION AWARENESS IMPROVEMENT
}

\author{
Nur Rahmiani, Norhayaty M. Malena \\ Institut Agama Islam Negeri Pontianak, Indonesia \\ Sekolah Kebangsaan Abang Leman Kabong Sarawak, Malaysia \\ nur.rahmiani02@iainptk.ac.id,nmme7mj23@gmail.com
}

Submitted: 2020-04-06

Accepted: 2020-04-20

\begin{abstract}
This work aims to analyze the existence of the English Club Project (ECP) for Vocational Midwifery Students (VMS) by developing an essay in terms of the output program relating to their professionalism. The program facilitates 30 students to build up motivation and awareness of punctuation in additional learning of writing skills. As it is developed from qualitative research, this article is based on the data collected through gathering diversified sources of evidence, organizing a chain of evidence, and having key-informants reviewing draft case study reports. The results present an additional learning model constructed by the representation of the ECP program. ECP is an informally productive community by providing activities and opportunities in increasing the motivation for writing and punctuation awareness. Students begin to understand that doing the writing is uncomplicated anymore after joining the extracurricular programs managed with structured and directed activities. Also, the facilitator provides valuable supports and integrates teaching methods with information and technology devices that made the learning activities quickly done - as for recommendations, strengthening the support to this model is necessary for the sustainability of this additional learning program.
\end{abstract}

Keywords: writing motivation; punctuation awareness; EFL community; informal learning

\section{INTRODUCTION}

Writing as one of the primary expertise in the context of supporting students' academic capacity has been believed to become a priority in Teaching English as a Foreign Language (TEFL). Writing as one of the extensive skills for educational purposes (Ghabool, Mariadass, \& Kashef, 2012; Hirvela, Nussbaum, \& Pierson, 2012) has such of complementary communication skills that intends to expose the meaning and to share the results of self-reflection, ideas, creativity in written forms (Daffern, Mackenzie, \& Hemmings, 2016). It also has kinds of needed knowledge, including many essential rules, such as grammar and syntax, and more detail in utilizing punctuation and writing instructions (Fareed, Ashraf, \& Bilal, 2016). Even for vocational students, writing English is more than a strategic stage after speaking proficiency as two priority skills in creating an academic product. Yet, it is in contrast to the real condition of students to accomplish their works with less motivation and less awareness of the appropriateness of grammar. They realize that this accomplishment is not as simple as the word motivation to say. Making some mistakes on inappropriate punctuation is a mostly problem for them (Shen, 2012). Not powerful enough in grammar teaching may also be a critical factor for motivation and punctuation awareness improvement. 


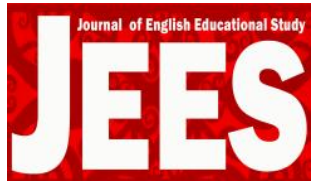

Journal of English Educational Study (JEES)

Volume 3 Issue 1 May 2020 Page 71-80

E-ISSN: 2655-0776

The authors believe that motivation is a part of human life sustainability to do actualization. Motivation is an internal control that comes up to commit something and to achieve some goals (Harmer, 2007). Motivation is full of the effort of personal preference on how to reach and respect the goals in life (Gardner, 2010; Keller, 1983; Orio, 2013). Motivation is needed and certainly dominating for successful of learning, including foreign language (Riyanti, 2019). Dörnyei (1994) classifies two theories of motivation, namely, intrinsic and extrinsic parts. Intrinsic motivation refers to something that appears from the personal internal power (Noels, Pelletier, Clement, \& Vallerand, 2003). It is related to psychology awareness to encourage anything about achievement. Meanwhile, extrinsic motivation refers to ex-factors which come up to complement the internal power like funding, reward, and even punishment (Brown, 2007). These two classifications empower the fruitfulness of learners for comprehending a foreign language.

Related to the skill of writing, whether full or less motivation, the authors analyze how EFL students always make some mistakes in a straightforward case that is about punctuation. Punctuation is one of the most frequently committed errors in writing English (Sermsook, Liamnimitr, \& Pochakorn, 2017). For example, students have difficulty in putting semicolons and commas, using capital and non-capital letters and spacing in computer typing (Nurlaili, 2018; Salman, Estefan, \& Yaseen, 2017; Samhon \& Abdall, 2016). This common error often happens both in the use of the first language-Bahasa Indonesia (L1) and English (L2), which are the primary and the instructional language of the students. Furthermore, many errors might be found in writing from EFL students. Those cases are strengthened by several studies describing investigations about common mistakes in punctuation found in the student writings (Awad, 2012; Nurlaili, 2018; Salman et al., 2017; Samhon \& Abdall, 2016). Other studies have also analyzed the relationship between punctuation and success in the writing process (Daffern et al., 2016; Ghabool et al., 2012).

In this work, the authors underline that this article differs from other studies. The authors endeavor to accentuate the contribution of an English community in a particular vocational institution called the English Club Project (ECP). ECP exists as an extracurricular activity in the vocational midwifery institution. It is the existence of the name of such clubs or gangs or groups that is a multinational phenomenon in increasing the interests and talents of a student (Malu \& Smedley, 2016). The participants of ECP called Vocational Midwifery Students (VMS), are non-English study program students and language use both L1 and L2. They are united as ECP members because united by the same skills, interests, and expectations (Pereira, Ismail, \& Othman, 2013). By emphasizing the ECP's contribution and also presenting its model, the authors pretend to highlight how the position of the community, program offered, how the 
role of the facilitator in achieving learning outcomes, and the impact felt by students after joining the ECP. The authors elaborate on two critical aspects of informal learning, namely writing motivation and punctuation awareness. The authors also accept that this issue is being a fascinating study because it deals with the component of the vocational curriculum.

\section{METHOD}

This study applies case-study design by seeking the answer to what, why, and how ECP provides an extracurricular activity to improve writing motivation and punctuation awareness. Moreover, the authors use a construct validity test to ensure the phase of research. First is gathering multiple sources of evidence. Second is establishing a chain of evidence. The third is having key-informants and reviewing draft case study reports (Yin, 2003) in the setting of the ECP model at Academy of Midwifery 'Aisyiyah Pontianak, which now exists in the new name as Politeknik Aisyiyah Pontianak in 2019. The ECP at the research setting consists of 30 VMS who are structured in the central committee and members. The committee and members take apart as informants in the activities of the ECP point to the shreds of evidence, and the project resulting from the ECP as the source and report. Kinds of data are gathered consisted of information about the positive and negative impacts of the model of locus ECP, the need analysis of the core aspect of the ECP model constructed for VMS, and how the process of making an essay based on the list of meetings. This action needs the triangulation process to support the result of the research analysis by presenting a picture of the ECP model.

\section{FINDING AND DISCUSSION}

The discovery of the ECP program can be delivered by some points listed below.

\section{Multiple Sources of The Impacts of ECP}

This work comes up with the division of the impacts into two kinds, namely positive and negative, with the explanation delivered as seen in Table 1.

Table 1. The Impacts of ECP

\begin{tabular}{|c|c|c|c|}
\hline No & The Impact of ECP & Positive & Negative \\
\hline 1. & $\begin{array}{l}\text { Students reveal } \\
\text { writing motivation }\end{array}$ & $\begin{array}{l}\text { a. Integrating teaching methods with } \\
\text { technology made ECP is quickly done. } \\
\text { b. The facilitator/lecturer's effect aroused } \\
\text { students' passion for writing. } \\
\text { c. The team works offered to finish on } \\
\text { time } \\
\text { d. Relaxing atmosphere supported fruitful } \\
\text { in the writing process. }\end{array}$ & $\begin{array}{l}\text { a. Its limitations vocabularies in the main } \\
\text { problem. } \\
\text { b. VMS wanted the reward but rejected the } \\
\text { punishment as a result of ECP is only an } \\
\text { extracurricular. } \\
\text { c. Independence and seriousness are faintly } \\
\text { visible. } \\
\text { d. Lecturer, as a facilitator program, led the } \\
\text { process adequately. }\end{array}$ \\
\hline 2. & $\begin{array}{l}\text { Students } \\
\text { comprehend } \\
\text { Punctuation } \\
\text { Awareness }\end{array}$ & $\begin{array}{l}\text { a. There is no doubt about using dot (.). It } \\
\text { means that VMS aware that dot is the } \\
\text { original punctuation in every single } \\
\text { text. } \\
\text { b. Integrating teaching methods with }\end{array}$ & $\begin{array}{l}\text { a. VMS still have a problem in putting the } \\
\text { punctuation of comma (,). } \\
\text { b. Several students didn't comprehend to use } \\
\text { technology for supporting punctuation } \\
\text { awareness. They prefer to choose a }\end{array}$ \\
\hline
\end{tabular}




\begin{tabular}{|c|c|c|c|}
\hline No & The Impact of ECP & \multicolumn{1}{|c|}{ Positive } & \multicolumn{1}{c|}{ Negative } \\
\hline & & $\begin{array}{l}\text { technology made the activity quickly } \\
\text { done. }\end{array}$ & $\begin{array}{l}\text { conventional approach that is directed to the } \\
\text { facilitator. }\end{array}$ \\
\hline
\end{tabular}

Sources: VMS'scripts analysis 2019

As described in table 1, the authors explore the need analysis of the core aspect of the ECP model constructed for VMS as ESP students. By Dudley-Evans and John's theory (2011), the authors express the findings, as stated in the next explanation.

\section{Establishing a chain of evidence and having key-informants reviewing the draft of the case study report.}

The evidence of why this model accomplishes the impact has been studied. The authors, based on the analysis, establish several points of view that can be seen in the following table.

Table 2. The ESP Aspect of Foundation of ECP Model

\begin{tabular}{|l|l|l|}
\hline No & \multicolumn{2}{|c|}{ The ESP Aspect of Foundation of ECP Model } \\
\hline 1 & $\begin{array}{l}\text { Student Personal } \\
\text { Information }\end{array}$ & $\begin{array}{l}\text { VMSs are more mature in desiring any problems that occurred in the learning phase. In contrast to } \\
\text { general students at any university, they split the time taking class and internship. They are forced } \\
\text { with the hectic schedule even it is in the first semester. Furthermore, they think that English is not } \\
\text { the priority course also they need this language for obligatory. }\end{array}$ \\
\hline 2 & $\begin{array}{l}\text { Language } \\
\text { information about } \\
\text { target situation }\end{array}$ & It is about fifty percent VMS at the beginner level of English skills. \\
\hline 3 & Learners' lacks & All aspect of English skills is trouble because of vocabularies are not powerful enough. \\
\hline 4 & $\begin{array}{l}\text { Learners need } \\
\text { from course }\end{array}$ & $\begin{array}{l}\text { English as Language 2 (L2) is used in medical terms. The use of language for long-term impact is } \\
\text { particular for competencies and job/vacancy. }\end{array}$ \\
\hline 5 & $\begin{array}{l}\text { Needs for } \\
\text { language learning }\end{array}$ & $\begin{array}{l}\text { The curriculum of KKNI (Kerangka Kualifikasi Nasional Indonesia) is used for the midwifery } \\
\text { study program. The curriculum is completed with English modules and other materials, including } \\
\text { grammar, subjects of matter, language use, and goals. }\end{array}$ \\
\hline 6 & $\begin{array}{l}\text { How to } \\
\text { communicate in } \\
\text { the target } \\
\text { situation }\end{array}$ & $\begin{array}{l}\text { Enacting reward and punishment is the better way to empower the target of learning. VMSs also } \\
\text { need a facilitator to manage the class. }\end{array}$ \\
\hline 7 & $\begin{array}{l}\text { Professional } \\
\text { information about } \\
\text { the learner }\end{array}$ & $\begin{array}{l}\text { VMS are ready to receive the components of the learning process like tasks, exercise, and other } \\
\text { activities, even though the necessary English skills are still low. }\end{array}$ \\
\hline
\end{tabular}

Sources: Facilitator'scripts analysis 2019

The existence of ECP stands on as an extracurricular for VMS in need only. The recruitment of the members is through hiring the interests and talents of students in a foreign language.

\section{The process of the ECP Model}

The ECP of the VMS program has ten initial meetings with the description below. In this part, the authors emphasize what the stages described, the output of each session, and evaluation of the process on the side of the facilitator and VMS. 
Table 3. The Process of ECP Based on the Meeting List

\begin{tabular}{|c|c|c|c|}
\hline No & Stages & Output & Evaluation \\
\hline 1 & $\begin{array}{l}\text { Overview of the need } \\
\text { for English and the } \\
\text { level of students' } \\
\text { capability }\end{array}$ & $\begin{array}{l}\text { VMS acquired the early } \\
\text { comprehension of ECP program } \\
\text { planning, and they realized where the } \\
\text { position of English ability is. }\end{array}$ & $\begin{array}{l}\text { a. VMS had been aware of participating in this group } \\
\text { because of improving their English ability. } \\
\text { b. VMS abilities averagely distributed as follows } \\
\text { beginner } 10 \% \text {, medium } 60 \% \text {, and intermediate } \\
30 \% \text {. }\end{array}$ \\
\hline 2 & $\begin{array}{l}\text { Group' and work' } \\
\text { division }\end{array}$ & $\begin{array}{l}\text { VMS divided the work into a small } \\
\text { group discussion (one group consists } \\
\text { of } 3 \text { persons) }\end{array}$ & $\begin{array}{l}\text { a. The division of tasks according to an agreement } \\
\text { that is in one group divided equally between the } \\
\text { very weak, weak, and moderate. } \\
\text { b. VMS responded positively related to group } \\
\text { division and assignment. }\end{array}$ \\
\hline 3 & $\begin{array}{l}\text { Determination the title } \\
\text { of the essay }\end{array}$ & $\begin{array}{l}\text { Students determine the title of the } \\
\text { writing and the conceptual } \\
\text { framework }\end{array}$ & $\begin{array}{l}\text { The proposed title includes the story of the } \\
\text { experience of parents or family of students who } \\
\text { served as midwives, local wisdom related to } \\
\text { midwifery, and general opinion regarding maternal, } \\
\text { child and family health }\end{array}$ \\
\hline 4 & Writing in L1 essays & $\begin{array}{l}\text { Students make a minimum of } 2 \\
\text { paragraphs }\end{array}$ & $\begin{array}{l}\text { a. Target two paragraphs reached } \\
\text { b. Difficulties are in word selection, and punctuation } \\
\text { is detected }\end{array}$ \\
\hline 5 & $\begin{array}{l}\text { Editing essays in L1 } \\
\text { writing I }\end{array}$ & $\begin{array}{l}\text { Students make a minimum of } 2 \\
\text { paragraphs }\end{array}$ & $\begin{array}{l}\text { a. Target two paragraphs reached } \\
\text { b. Difficulties in the choice of words and punctuation } \\
\text { can be overcome by providing enrichment. }\end{array}$ \\
\hline 6 & $\begin{array}{l}\text { Editing essays in L1 } \\
\text { writing II }\end{array}$ & $\begin{array}{l}\text { Students can correct writing structure } \\
\text { and punctuation errors }\end{array}$ & $\begin{array}{l}\text { a. The teamwork system is a bit difficult because } \\
\text { editing requires concentration and calmness. } \\
\text { b. VMS and facilitators agreed to appoint one } \\
\text { specific person for writing and then continued } \\
\text { sharing between teams. }\end{array}$ \\
\hline 7 & $\begin{array}{l}\text { Translating essays into } \\
\text { L2 I }\end{array}$ & $\begin{array}{l}\text { Students can translate English using } \\
\text { online and offline media assisted by } \\
\text { supervisors. }\end{array}$ & $\begin{array}{l}\text { By paying attention to the necessary abilities of } \\
\text { VMS, the integration of using IT is as a way to } \\
\text { encourage their motivation to write. }\end{array}$ \\
\hline 8 & $\begin{array}{l}\text { Translating essays into } \\
\text { L2 II }\end{array}$ & $\begin{array}{l}\text { Students can translate English using } \\
\text { online and offline dictionaries } \\
\text { assisted by VMS supervisors who } \\
\text { enthusiastically combine IT functions } \\
\text { and offline media to help translate } \\
\text { essays }\end{array}$ & $\begin{array}{l}\text { VMS is enthusiastic about combining IT functions } \\
\text { and offline media to help translate essays }\end{array}$ \\
\hline 9 & $\begin{array}{l}\text { Translating essays into } \\
\text { L2 III }\end{array}$ & $\begin{array}{l}\text { Students can translate English using } \\
\text { online and offline dictionaries } \\
\text { assisted by VMS supervisors who } \\
\text { enthusiastically combine IT functions } \\
\text { and offline media to help translate } \\
\text { essays }\end{array}$ & $\begin{array}{l}\text { Error on the Grammarly online checker noted: } \\
\text { a. Missing coma } 68,42 \% \\
\text { b. Incorrect comma splice } 13,68 \% \\
\text { c. Overused comma } 8,42 \% \\
\text { d. Capitalization awareness } 4,73 \% \\
\text { e. Incorrect punctuation } 2,63 \% \\
\text { f. Inconsistent punctuation } 1,58 \% \\
\text { g. Missing hyphen } 0,53 \%\end{array}$ \\
\hline 10 & $\begin{array}{l}\text { Completion of the final } \\
\text { essay results }\end{array}$ & $\begin{array}{l}\text { Students can improve the structure of } \\
\text { language and punctuation assisted by } \\
\text { the supervisor lecturer }\end{array}$ & $\begin{array}{l}\text { Errors that arise in the punctuation checker are } \\
\text { completed immediately. }\end{array}$ \\
\hline
\end{tabular}


From the ten processes of how facilitators and students having contingently and continuity activities, the authors present the picture of mechanisms of the ECP model directly formed, as seen in figure 1 below.

Figure 1. The Mechanism of the ECP Model

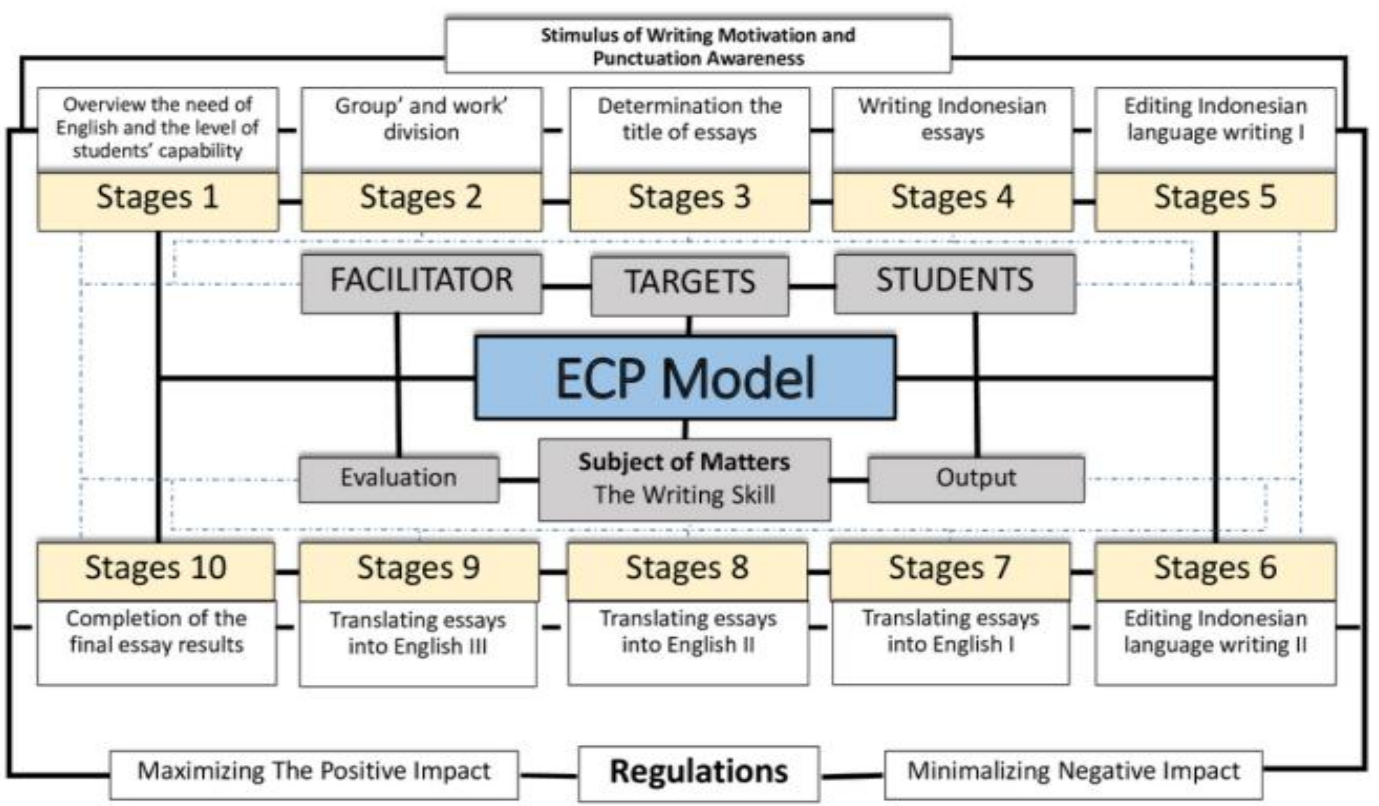

By this figure, the intentions to all stages of the ECP model occur on the process strengthened by the regulations on how the facilitators and students get involved in the writing process. The stimulus has a role in maximizing the positive impact, and to minimal, the negative impact is based on the evaluation in every process. This way can be called a stimulation model of ECP of how this model functions to supports writing motivation and punctuation awareness.

The ECP may become the characteristic of a particular club that promotes the learning outcomes and scholarship profile. It may also offer a program to encourage intrinsic and extrinsic power. By joining this club, VMS are able to write articles or essays that are considered difficult by students who are not from an English study program. Without motivation and knowledge of writing and punctuation, the activity will not be easy to do. No successful students get high language achievement to comprehend bilingual or multilingual skills without spirited motivation (Aryanika, 2016).

Focusing on the use of punctuation, the authors notice at the critical view of how punctuation functions as one of the forms that explicitly occur to become marks in a sentence. This sign of the marks serves to give instructions in analyzing the meaning of grammatical construction. Because of its powerful function in the process of language learning, the inappropriateness of putting and using punctuation will provide effects for the readers in interpreting the meaning of a text. In other words, the use of punctuation gives significant 
implications to the comprehension of the readers in reading a sentence. If the work uses minimal punctuation, then the readers will experience a decrease in the understanding of the punctuation marks (Baldwin \& Coady, 1978). To recall forms of punctuation and sentence structure functions, the following aspects are displayed, (Butterworth, 1999; Krikman, 2006; Straus, 2008), namely a spacing with punctuation, a period, an ellipsis mark, and others. As a description, many kinds of punctuation can be used with many functions. Only a few punctuations are often used in writing as spacing with punctuation, a period, a comma, an apostrophe, a colon, and quotation marks.

In the context of EFL, an English club is made as to the belief of EFL teachers as a way to push efforts of students to improve their language skills. However, it has a positive impact on increasing hours of enrichment and increasing the motivation of participants to learn through routine activities (Zachar, 1938). The activity guides and demands the active role of vocational students following step by step until they produce a proud work. Various countries and various institutions have used the English club project itself (Malu \& Smedley, 2016; Pereira et al., 2013; Zulhermindra, 2018). By limiting the points of writing motivation and awareness in the use of punctuation, this work focuses on a specific part in addition to meeting the realm of research in English development. The ECP Learning Model is also considered to be following the curriculum of vocational schools.

From the mechanism of how the ECP stands for, the authors emphasize that every stage has particular aims with the structure, as shown in Table 3 and Figure 1. The authors figure several meaningful discussion based on the data result. First is the overview of the need for English and the level of students' capability. The authors propose that the VMS acquired the early comprehension of ECP program planning, and they realized where the position of English ability is. It seems that vocational learning requires a need analysis step to identify the needs and achievements of students both in the content and context of language learning (Rahmiani, Salam, \& Supardi, 2018). In this stage, the authors find out that limitation vocabularies are in the main problem of VMS.

The second discussion is VMS divided the work into a small group discussion (one group consists of 3 persons). The division of tasks according to an agreement that is in one group divided equally among the beginner, medium, and intermediate. The VMS respond positively related to group division and assignment. Combining those who have beginner, medium, and intermediate level skill of English, it makes the writing is easily done. This statement is strengthened by Burke (2011) that group work excites creativity, allows remaining to each other, creates a satisfying decision, and makes it easy to get more information. Group 
mates in the writing activities are one of the primary factors reflecting on the students' motivation (Gai Mali, 2015).

The third, VMS, together with the facilitator, determines the title of the writing and the conceptual framework. The proposed title includes the story of the experience of parents or family of students who served as midwives, local wisdom related to midwifery, and general opinion regarding maternal, child, and family health. It means that the facilitator as a critical stimulus for students to encourage their motivation in writing an essay. ESP, as like, they are midwifery students; thus, the content of writing is better if the topic also related to them. The content-based writing supports better comprehension in the vocabularies, grammar, reading, and writing (Khonsari, 2005). The fourth writing process, both an essay in L1 and L2, giving the target how many paragraphs and how long the time need, and the translating process make VMS aware of the difficulties. Then, the facilitator assists them in detecting the writing problems such as word selection, and punctuation. Together with groupmates, VMS motivate each other because of the instruction from the facilitator. Lam (2007) argues that performance in writing can be better when the teacher effect motivated the students.

The fifth stage is paying attention to the necessary abilities of VMS in the integration of using technology is a way to encourage their motivation to write. VMS is enthusiastic about combining technology functions and offline media to help translate essays. As stated by Boudjadar (2015), using technology in teaching writing is the better way to yield positive outcomes compared to paper-based writing. This way, by instructions from the facilitator, the ECP allows students to use online and offline dictionaries. Recommended technology such as Grammarly online checker assists VMS noted the incorrect punctuation. The results of some researches confirm that Grammarly has significant reduction errors and improving writing quality (Ghufron \& Rosyida, 2018; Karyuatry, Rizqan, \& Darayani, 2018).

\section{CONCLUSION}

To sum up, the authors underline a path for stimulating motivation for writing and punctuation awareness of VMS named ECP model. Students realize that writing was uncomplicated anymore after joining this extracurricular activity, which is managed with structured and directed activities. The ECP has become an alternative for extra student activity programs, which, of course, must be managed optimally. The facilitator support and integrating teaching method with technology made this activity quickly done. Then, remembering that writing, technically, is a productive activity that requires three aspects: students' activities, lecturer' facilitation, and evaluation process to build the best learning output. This article explains the importance of informal learning as a supplement activity for students who have the same skills, interests, and expectations to improve English, mainly writing abilities. Suggestions 
for the future, it was necessary to strengthen the support from the institution and facilitator for the sustainability community program in terms of providing several of student products.

\section{REFERENCES}

Aryanika, S. (2016). The Correlation Between the Students' Writing Motivation and the Writing Ability. English Education: Jurnal Tadris Bahasa Inggris, 9(1), 215-232. Retrieved from https://media.neliti.com/media/publications/60527-EN-the-correlation-between-thestudents-wri.pdf

Awad, A. (2012). The Most Common Punctuation Errors Made by the English and the TEFL Majors at An-Najah National University. An - Najah Univ. J. Res. (Humanities)., 26(1). Retrieved from https://journals.najah.edu/article/97/

Baldwin, R. S., \& Coady, J. M. (1978). Psycholinguistic approaches to a theory of punctuation. Journal of Literacy Research. https://doi.org/10.1080/10862967809547290

Boudjadar, T. (2015). ICT in the writing classroom: The pros and the cons. International Journal of Applied Linguistics and English Literature, 4(1), 8-13. https://doi.org/10.7575/aiac.ijalel.v.4n.1p.8

Brown, H. D. (2007). Principles of Language Learning and Teaching. USA: Longman.

Burke, A. (2011). How To Use Groups Effectivley. The Journal of Effective Teaching, 11(2), 8795. Retrieved from https://uncw.edu/jet/articles/vol11_2/burke.pdf

Butterworth, J. (1999). Punctuation. Oxford: Oxford University Press.

Daffern, T., Mackenzie, N. M., \& Hemmings, B. (2016). Predictors of writing success : How important are spelling , grammar and punctuation? https://doi.org/10.1177/0004944116685319

Dörnyei, Z. (1994). Motivation and Motivating in the Foreign Language Classroom. The Modern Language Journal, 78(3), 273-284.

Dudley-Evans, T., \& John, M. J. (2011). Developments in English for Specific Purposes. UK: Cambridge.

Fareed, M., Ashraf, A., \& Bilal, M. (2016). ESL Learners' Writing Skills: Problems, Factors and Suggestions. Journal of Education \& Social Sciences, 4(2), 83-94. https://doi.org/10.20547/jess0421604201

Gai Mali, Y. C. (2015). Motivational Factors in the Indonesian Efl Writing Classroom. Jurnal Pendidikan Bahasa Dan Sastra, 15(1), 1. https://doi.org/10.17509/bs_jpbsp.v15i1.794

Gardner, C. R. (2010). Motivation and Second Language Acquisition: The Socio-Educational Model. New York: Peter Lang Publishing.

Ghabool, N., Mariadass, M. E. A., \& Kashef, S. H. (2012). Investigating Malaysian ESL Students' Writing Problems on Conventions, Punctuation, and Language Use at Secondary School Level. Journal of Studies in Education, 2(3), 130-143. https://doi.org/10.5296/jse.v2i3.1892

Ghufron, M. A., \& Rosyida, F. (2018). The Role of Grammarly in Assesing English As A Foreign Language (EFL) Writing, 12(November), 395-403. https://doi.org/10.21512/lc.v12i4.4582

Harmer, J. (2007). The Practice of English Language Teaching (4th ed.). Harlow: Person Education.

Hirvela, A., Nussbaum, A., \& Pierson, H. (2012). ESL Students 'Attitudes Toward Punctuation. System, 40(1), 11-23. https://doi.org/10.1016/j.system.2012.01.006

Karyuatry, L., Rizqan, M. D. A., \& Darayani, N. A. (2018). Grammarly As A Tool To Improve Students' Writing Quality: Free Online-Proofreader Across The Boundaries. Edulitics Journal, 3(1), 36-42.

Keller, J. . (1983). Motivational Design of Instruction. Instructional Design Theories and Models: An Overview of Their Current Status. (C. M. Reigelruth, Ed.). Hills-dale, NJ: Lawrence Erlbaum. 
Khonsari, S. (2005). Approaches to Content-Based Academic Writing. The Journal of Asia TEFL, 2(2), 117-137. https://doi.org/10.2307/3586515

Krikman, J. (2006). Punctuation Materrs (4th ed.). London and New York: Routledge.

Lam, S. F., \& Law, Y. K. (2007). The roles of instructional practices and motivation in writing performance. Journal of Experimental Education, 75(2), 145-164. https://doi.org/10.3200/JEXE.75.2.145-164

Malu, K. F., \& Smedley, B. (2016). Community-Based English Clubs : English Practice and Social Change Outside the Classroom. English Teaching Forum. Retrieved from https://files.eric.ed.gov/fulltext/EJ1114170.pdf

Noels, K. ., Pelletier, L. ., Clement, R., \& Vallerand, R. J. (2003). Why Are You Learning A Second Language? Motivational Orientations And Self-Determination Theory. In Z. Dörnyei (Ed.), Attitudes, Orientations, and Motivation in Language Learning (pp. 33-63). Malden: Blackwell Publishing.

Nurlaili. (2018). An Error Analysis on The Use of Punctuation Marks in Students' Writing (A Study at Second Semester Students of English Department of Universitas Muhammadiyah Surakarta). Retrieved from http://eprints.ums.ac.id/65167/12/NASKAH PUBLIKASI REVISI-Far.pdf.

Orio, S. F. (2013). Motivation and Second Language Acquisition.

Pereira, A. H., Ismail, K., \& Othman, Z. (2013). A Model for the Malaysian English Language Club Activities. Procedia - Social and Behavioral Sciences, 90, 48-56. https://doi.org/10.1016/j.sbspro.2013.07.064

Rahmiani, N., Salam, U., \& Supardi, I. (2018). Developing a Supplementary Material of Malay Tourism for Vocational Students in Pontianak West Kalimantan. Script Journal: Journal of Linguistic and English Teaching, 3(2), 127. https://doi.org/10.24903/sj.v3i2.232

Riyanti, D. (2019). the Role of Motivation in Learning English As a Foreign Language. JELTIM (Journal of English Language Teaching Innovations and Materials), 1(2), 29. https://doi.org/10.26418/jeltim.v1i1.27788

Salman, H. D., Estefan, M., \& Yaseen, N. Y. (2017). Errors in Using Punctuation Marks in Selected Scientific Writing Committed By Non- Native Postgraduate. Scientific Research Journal (SCIRJ), V(IV), 7-18. Retrieved from http://www.scirj.org/papers-0417/scirjP0417396.pdf

Samhon, E. A. M. S., \& Abdall, Y. A. (2016). Common Punctuation Errors Made by Secondary Schools Students in English: A Case Study at Secondary Schools, Nyala Locality. Journal of Humanities, 17(4). Retrieved http://www.sustech.edu/staff_publications/20161215114241110.pdf.

Sermsook, K., Liamnimitr, J., \& Pochakorn, R. (2017). An Analysis of Errors in Written English Sentences: A Case Study of Thai EFL Students. English Language Teaching, 10(3), 101. https://doi.org/10.5539/elt.v10n3p101

Shen, Y. (2012). Reconsidering English grammar teaching for improving non-English majors' English writing ability. English Language Teaching, 5(11), 74-78. https://doi.org/10.5539/elt.v5n11p74

Straus, J. (2008). The Blue Book of Grammar and Punctuation. San Fransisco: Jossey-Bass.

Yin, K. R. (2003). Case Study Research Design and Methods (3rd ed.). California: Sage Publication.

Zachar, I. J. (1938). Activities for the Class English Club. The English Journal, 27(2). https://doi.org/10.2307/806209

Zulhermindra. (2018). Promoting English Club As An Extracurricular Activity For Young Learners: Suggested Procedure. 3rd International Conference on Education 2018 Teachers in the Digital Age, 286-288. Retrieved from http://ecampus.iainbatusangkar.ac.id/ojs/index.php/proceedings/article/view/1331 